\title{
DiKili Sebagai Ekspresi Islam Nusantara dalam Budaya Islam Lokal Gorontalo : Perspektif Dakwah Islamiyah
}

\author{
Erwin Jusuf Thaib \\ IAIN Sultan Amai Gorontalo \\ erwinthaib7578@gmail.com
}

\begin{abstract}
Preaching has been deployed with a variety of media and approaches used. One medium of propaganda that is often used is culture. This phenomenon can be found in the majority culture of Gorontalo people embraced Islam. Melting the boundaries between religion and culture is a common thing for people of Gorontalo. Dikili is seen as one of the expressions of Islam Nusantara in Islamic culture of Gorontalo. Moral messages contained in the narrative Kitabi Lo Dikili relevant to preaching in general involves two aspects, aspects of the teachings of monotheism and moral teaching aspect / character of the Prophet Muhammad. Both of these aspects stand as it relates to the social setting that is faced by the Prophet when preaching for the first time in the city of Mecca.
\end{abstract}

\begin{abstract}
Abstrak
Dakwah telah disebarkan dengan berbagai macam media dan pendekatan yang digunakan. Salah satu medium dakwah yang sering digunakan adalah kebudayaan. Fenomena seperti ini dapat ditemukan dalam budaya masyarakat Gorontalo yang mayoritas memeluk agama Islam. Meleburnya batas antara agama dan budaya merupakan hal yang lazim bagi masyarakat Gorontalo. Tradisi dikili dipandang sebagai salah satu ekspresi Islam Nusantara dalam budaya Islam Gorontalo. Pesan-pesan moral yang termuat dalam narasi Kitabi Lo Dikili yang relevan dengan dakwah pada umumnya menyangkut dua aspek yakni aspek ajaran tauhid dan aspek ajaran moral / akhlak Nabi Muhammad saw. Kedua aspek ini menonjol karena berkaitan dengan setting sosial yang dihadapi oleh Nabi Muhammad saw ketika berdakwah untuk pertama kalinya di Kota Mekah.
\end{abstract}

Keywords; Dikili, Preaching, Gorontalo 


\section{A. Pendahuluan}

Kebudayaan ${ }^{1}$ adalah suatu fenomena universal. Setiap masyarakatbangsa di dunia ini memiliki kebudayaan, meskipun bentuk dan coraknya berbeda-beda dari masyarakat-bangsa yang satu ke masyarakat-bangsa yang lainnya. Sebagai ciptaan manusia, kebudayaan adalah ekspresi eksistensi manusia di dunia. Manusia dan kebudayaan merupakan kesatuan yang tidak terpisahkan, manusia adalah makhluk pencipta sekaligus sebagai pendukung kebudayaan itu sendiri. ${ }^{2}$

Ada tiga karakteristik penting dari kebudayaan, yaitu: (1) kebudayaan itu dapat dipelajari, (2) kebudayaan itu dapat dipertukarkan, dan (3) kebudayaan itu tumbuh dan berkembang ${ }^{3}$. Kebudayaan sebagai suatu sistem pengetahuan merupakan alat esensial bagi manusia untuk mengatasi masalah yang dihadapi dari lingkungan fisik, sosial maupun spritual. Manusia selalu berupaya untuk menyesuaikan dirinya dengan berbagai perubahan yang terjadi disekitarnya sehingga melahirkan suatu pola-pola tingkah laku yang baru. Keberhasilan manusia menyesuaikan diri dan menundukkan alam sekitarnya adalah bukti keberhasilan mereka mencapai suatu tingkat kebudayaan yang tinggi. ${ }^{4}$

Kebudayaan dalam relitasnya adalah perpaduan dari berbagai unsur yang terdapat dalam kehidupan masyarakat, yang senantiasa dilaksanakan, dipelihara, dan dilestarikan sebagai perwujudan keluhuran budi pekerti suatu bangsa. Semua itu berwujud dalam bentuk artefakartefak, bangunan, seni tari, seni tutur, termasuk di dalamnya tradisi lisan.

1 Istilah kebudayaan atau culture dalam bahasa Inggris, berasal dari kata kerja bahasa Latin colere yang berarti mengolah, mengerjakan, terutama mengolah tanah atau bertani. Arti ini berkembang menjadi culture sebagai segala daya upaya serta tindakan manusia untuk mengolah tanah dan merubah alam. Dalam bahasa Indonesia. Kata kebudayaan berasal dari bahasa Sansekerta buddhayah, yaitu bentuk jamak dari kata buddhi (budi dan daya) yang berarti daya dari budi, yaitu berupa cipta, karsa dan rasa. Koentjaraningrat mendefinisikan kebudayaan merupakan : "keseluruhan sistem gagasan, tindakan dan hasil karya manusia dalam rangka kehidupan masyarakat yang dijadikan milik diri manusia dengan belajar". Lihat Koentjaraningrat, Manusia dan Kebudayaan di Indonesia (Jakarta: Djambatan, 1980) h. 3

${ }^{2}$ Hari Purwanto, Kebudayaan dan Lingkungan Dalam Perspektif Antropologi (Yogyakarta: Pustaka Pelajar, 2000) h. 87

${ }^{3}$ Alo Liliweri, Makna Budaya Dalam Komunikasi Antar Budaya (Jakarta: LKiS Pelangi Aksara, 2003) h. 57

${ }^{4}$ T.O. Ihromi, Pokok-pokok Antropologi Budaya (Jakarta: Yayasan Obor Indonesia, 2000) h. 28 
Dan semua itu berlaku pada seluruh suku bangsa termasuk suku bangsa Gorontalo.

Gorontalo, sebagaimana diungkapkan Van Vollenhoven ${ }^{5}$, merupakan salah satu daerah adat dari 9 daerah adat di Nusantara. Masyarakat Gorontalo memiliki latar budaya progresif yang kuat. Salah satu gambaran progresifitasnya adalah sifat pemerintahannya yang demokratis. Kerajaan-kerajaan Gorontalo terbentuk atas kemauan rakyat bersama, maka kerajaan maupun alat-alat kelengkapannya harus mencerminkan masyarakat itu secara keseluruhan. Salah satu kelengkapan kerajaan disebut dengan Bantayo Poboide (Dewan Rakyat), dimana lembaga ini pernah memveto peralihan kekuasaan secara langsung dari Raja Ilahudu kepada putranya Uloli dan tetap meminta pemilihan oleh rakyat walaupun calonnya adalah anak raja. ${ }^{6}$ Semula mereka adalah nomaden di sekitar lereng perbukitan tergenang air (huntu langi-langi). Pada perkembangan selanjutnya, melalui prinsip demokrasi yang kuat, mereka membentuk negara federasi (pohalaa) Hulonthalo. Pohalaa ini diletakkan pada prinsip dasar pemerintahan dan ketatanegaraan yang tidak lepas dari warna ajaran Islam ${ }^{7}$. Salah satu aspek yang menonjol dari suku Gorontalo adalah tradisi lisan yang sangat kental dengan budaya masyarakat. Selain dikili, tradisi lisan lain yang populer di masyarakat Gorontalo antara lain berupa me'eraji, turunani, buruda, pandungi, tinilo, tuja'i, tanggomo, gambusi, dana-dana, dan lain sebagainya.

Kekayaan tradisi lisan merupakan fenomena budaya masyarakat. Sebagai bukti fenomena budaya tersebut, tradisi lisan akan menjadi pencerminan situasi, kondisi, dan adat istiadat suatu masyarakat tertentu. Teeuw mengatakan bahwa kekayaan tradisi lisan dari berbagai suku bangsa direkam dan diselamatkan dalam bentuk tulisan, dan ternyata dari segi kuantitas dan kualitas, tradisi lisan itu luar biasa kayanya dan beraneka ragam. Dalam tradisi lisan setiap daerah terungkap kreativitas bahasa yang luar biasa, dari hasil tradisi lisan tersebut manusia dapat mewujudkan

\footnotetext{
${ }^{5}$ Cornelis van Vollenhoven, Van Vollenhoven on Indonesian Adat Law (Leiden: KITLV, 2013 ) h. 44

${ }^{6}$ S.R. Nur dkk, Kerakyatan Sebagai Azas Ketatanegaraan Adat Sulawesi (Ujung Pandang: Percetakan LEPPEN YBW-UMI, t.th.) h.21-22 \& 98

${ }^{7}$ Alim Niode dan Elnino, Abad Besar Gorontalo (Gorontalo: Presnas Publishing, 2003) h. 8
} 
hakikat mengenai dirinya sendiri sehingga sampai sekarangpun ciptaan itu mempunyai nilai dan makna yang luhur. ${ }^{8}$

Tradisi lisan banyak disetiap daerah, termasuk di Gorontalo. Daerah Gorontalo yang dikenal dengan budayanya sangat menghargai tradisi yang sudah lama turun temurun dipertahankan oleh masyarakat sebagai pemilik tradisi tersebut. Tradisi itu antara lain ritual maulidan yang ditandai dengan tradisi lisan dikili.

Dikili sebagai tradisi lisan dalam ritual maulidan merupakan salah satu warisan budaya leluhur masyarakat Gorontalo yang berperan 'membingkai' moral generasi dan masyarakat karena memiliki nilai-nilai yang dapat dijadikan acuan dalam kehidupan mereka. Pesan-pesan kehidupan yang terkandung dalam ritual maulidan ini dapat menjadi landasan bertindak dan bertingkah laku bagi generasi selanjutnya dalam segala aspek kehidupan. ${ }^{9}$

Mencermati keberadaan tradisi lisan dikili di atas, maka sangat disayangkan jika masyarakat Gorontalo sudah kurang bersimpati terhadap kekayaan budaya yang telah diwariskan oleh para pendahulu itu. Berbagai tardisi lisan/tulisan yang dimiliki oleh masyarakat Gorontalo memang banyak mengungkap berbagai nilai yang dapat dijadikan pedoman dalam kehidupan bermasyarakat tapi masih banyak yang belum disentuh oleh para ilmuan. Demikian halnya dengan tradisi lisan dikili juga belum dikaji secara ilmiah.

Dikili sebagai tradisi dalam ritual maulidan memiliki beragam simbol, nilai-nilai, makna bahasa dalam kehidupan masyarakat. Meskipun demikian, karena pelaksanaan tradisi ini lebih didorong oleh semangat agama untuk mengagungkan hari kelahiran Nabi Muhammad saw, maka salah satu tendensi yang termuat dalam tradisi ini penyebarluasan nilainilai luhur yang berkaitan dengan kepribadian Nabi Muhammad saw, baik kepada pelaku dikili maupun kepada masyarakat pendengar. Tujuan tersirat dari tradisi lisan dikili sebagaimana diungkapkan di atas tampkanya sejalan dengan tujuan dakwah Islamiyah yang ingin menyebarluaskan ajaran Islam melalui berbagai pendekatan termasuk melalui pendekatan budaya sebagaimana halnya dengan tradisi lisan dikili

\footnotetext{
${ }^{8}$ A. Teeuw, Sastra dan Ilmu Sastra, Pengantar Ilmu Sastra (Jakarta: Pustaka Jaya, 1984) h. 10

${ }^{9}$ Ellyana Hinta, Simbol Verbal dan Non Verbal dalam Tradisi Maulidan Sebagai Konteks Tradisi Lisan di Gorontalo (t.tp: Prosiding Seminar Internasional Multikultural dan Globalisasi, 2012) h. 145
} 
dalam budaya Gorontalo. Relasi antara budaya dan agama dalam masyarakat Gorontalo dipandang sebagai salah satu wujud dari ekspresi Islam Nusantara di Indonesia. Berdasarkan uraian dalam latar belakang di atas, maka terdapat dua aspek yang menjadi permasalahan dalam artikel ini yakni bagaimana corak keagamaan masyarakat Gorontalo dan bagaimana dikili menjadi suatu varian budaya Islam Gorontalo.

\section{B. Corak Keagamaan Masyarakat Gorontalo}

Hampir dipastikan penduduk asli Gorontalo seluruhnya memeluk agama Islam (meskipun sulit memastikan seberapa besar kadar keislamanya). Jika tiba-tiba kedapatan ada diantara mereka yang tidak beragama Islam maka hampir dapat dipastikan mereka dari kalangan murtad atau keturunannya dan jumlah mereka tidak seberapa.

Masyarakat Gorontalo dari segi agama identik dengan Islam. Pandangan hidup dan adat istiadat yang berlandaskan Islam yang telah menyatu dalam kehidupan mereka (ma lo tombowata), menyebabkan penduduk asli Gorontalo malu jika disebut bukan Islam (dila tiluna/tidak disunat). Suatu sindiran yang seolah menyatakan bahwa seseorang itu bukan Islam. Bahkan mereka merasa dihina dan tak jarang bisa mengakibatkan pembunuhan. Sedangkan mereka yang menjadi murtad sebagian besar (tidak menyebut seluruhnya) harus pindah kedaerah lain.

Secara umum kehidupan beragama di Gorontalo berlangsung secara kondusif. Hal ini mengingat bahwa Gorontalo merupakan wilayah yang sangat menjunjung tinggi kebudayaan lokal yang diwariskan oleh para leluhur. Di samping itu peran agama juga sangat kuat memberikan pengaruh yang signifikan bagi masyarakat di Gorontalo, utamanya Islam yang dianut oleh sekitar 97,32 \% penduduk Gorontalo. Sementara 2,68\% selebihnya adalah penganut Kristen, Katolik, Hindu dan Budha. ${ }^{10}$

Berdasarkan data demografis di atas, Gorontalo merupakan wilayah yang dihuni oleh penduduk yang mayoritas beragama Islam. Sejak awal keberadaan Islam sebagai agama dan keyakinan resmi di kalangan masyarakat Gorontalo, sejak itu pula Islam menjadi sandaran dan rujukan bagi keseluruhan aktivitas hidup masyarakat Gorontalo, baik itu yang berkaitan dengan ritual atau syariat, maupun aktivitas tersebut yang berkaitan dengan adat dan kebiasaan hidup sehari-hari. Hal demikian dapat

\footnotetext{
${ }^{10}$ Mashadi, Realitas Keagamaan dalam Masyarakat Gorontalo antara Tuntunan Syariat dan Tuntutan Budaya, dalam Sofyan AP Kau (Editor) Islam dan Tradisi Kearifan Lokal Gorontalo (Gorontalo, Sultan Amai Press: 2013) h. 119
} 
dipahami bahwa Gorontalo dikenal dengan falsafahnya yakni : "Adati hula hula'a to sara'a, sara'a hula hula'a to Kuru'ani" yang diartikan : "adat bersedi syara' dan syara' bersendi Kitabullah. Falsafah inilah yang kemudian menjadi bingkai dari tradisi Islam Gorontalo. ${ }^{11}$

Nilai kearifan tersebut merupakan falsafah hidup masyarakat Gorontalo yang telah dirumuskan sejak Raja Amai yang konsepnya mengalami penyempurnaan tiga kali sampai Raja Eyato sehingga menjadi konsep yang dikenal hingga hari ini. Kearifan lokal Gorontalo seperti yang tergambar dalam falsafah "Adat bersendi syara', syara' bersendi Kitabullah", menjadi warna dan corak tersendiri bagi pelaksanaan dan pengimplementasian nilai-nilai agama di Gorontalo. Nilai-nilai kearifan tersebut telah menjadi pemberi spirit bagi keseluruhan aktivitas hidup masyarakat Gorontalo bahkan sejak pertama kali Islam dikenal oleh masyarakat Gorontalo.

Dalam berbagai perspektif, kearifan lokal "Adati hula hula'a to sara'a, sara'a hula hula'a to Kuru'ani", ditanggapi dan dipersepsikan oleh berbagai kalangan sebagai penentu bagi perjalanan dan konstruksi budaya masyarakat Gorontalo pada masa lalu menuju masa depan yang civilize (berperadaban) ${ }^{12}$

Hal inilah yang menyebabkan Islam sudah menjadi identitas kultural masyarakat Gorontalo. Falsafah "Adati Hulo-huloA to Syara'a, Syara'a Hulo-huloA to Kuru'ani, " bukan hanya sebuah filosofi kehidupan yang tidak implementatif dalam kehidupan masyarakat Gorontalo tetapi secara nyata ada dalam kehidupan masyarakat Gorontalo. Karena falsafah ini merupakan formulasi nilai-nilai lokal Gorontalo, yang oleh faktor eksternal dan internal mempengaruhi perubahan sosial, menjadikan prinsip tersebut menjadi mozaic culture. Rumusan-rumusan falsafah Gorontalo baik yang bermula pada zaman Raja Amai hingga rumusan ketiga yang dianggap sempurna pada zaman Raja Eyato, telah dipandang paripurna memberi pancaran nilai keagamaan dan nilai sosial bagi masyarakat Gorontalo secara universal. ${ }^{13}$

\footnotetext{
${ }^{11}$ Mashadi, Realitas Keagamaan dalam Masyarakat Gorontalo antara Tuntunan Syariat dan Tuntutan Budaya, h. 120

${ }^{12}$ Mashadi, Realitas Keagamaan dalam Masyarakat Gorontalo antara Tuntunan Syariat dan Tuntutan Budaya, h. 121

${ }^{13}$ Mashadi, Realitas Keagamaan dalam Masyarakat Gorontalo antara Tuntunan Syariat dan Tuntutan Budaya, h. 123
} 
Sejak rumusan pertama oleh Sultan Amai (1532-1550), telah terbentuk paradigma keberagamaan yang bercorak adat, yang mana paradigma tersebut telah berhasil membentuk watak kebudayaan Islam yang melahirkan versi Islam yang diadatkan.

Ketetapan-ketetapan agama dan adat dari pemerintahan Islam Gorontalo di masa lalu telah ikut mempengaruhi kehidupan beragama masyarakat Gorontalo hingga hari ini. Selain muncul dalam berbagai upacara adat yang berkaitan dengan seluruh aspek kehidupan masyarakat Gorontalo, corak keislaman sebagai warisan dari ketetapan masa lalu terlihat dari berbagai budaya masyarakat Gorontalo. Interaksi Islam dengan budaya lokal dapat dianalisa dalam konteks sosiohistoris, seperti terjadi dalam pola penyebaran Islam masyarakat suku Gorontalo. Interaksi Islam dengan budaya lokal adalah sebagai upaya melihat hubungan dinamis antara Islam dengan berbagai nilai dan konsep kehidupan yang dipelihara dan diwarisi serta dipandang sebagai pedoman hidup oleh masyarakat terkait. Pedoman hidup dimaksud juga mencakup tradisi yang diwarisi dari generasi ke generasi yang hingga kini fenomenanya masih nampak. ${ }^{14}$

Salah satu aspek yang menonjol dari budaya Gorontalo adalah tradisi lisan yang sangat kental dengan budaya masyarakat. Selain dikili, tradisi lisan lain yang populer di masyarakat Gorontalo antara lain berupa me'eraji, turunani, buruda, pandungi, tinilo, tuja'i, tanggomo, gambusi, dana-dana, dan lain sebagainya. Tradisi lisan ini diselenggarakan dalam berbagai momen yang terjadi dalam kehidupan masyarakat Gorontalo. Tradisi lisan ini penuh dengan pesan-pesan Islam yang bertujuan untuk menjadi tuntunan hidup bagi para pendengarnya. Semua tradisi ini masih hidup dan eksis dalam masyarakat Gorontalo hingga hari ini.

Kekayaan tradisi lisan merupakan fenomena budaya masyarakat. Sebagai bukti fenomena budaya tersebut, tradisi lisan akan menjadi pencerminan situasi, kondisi, dan adat istiadat suatu masyarakat tertentu. Teeuw mengatakan bahwa kekayaan tradisi lisan dari berbagai suku bangsa direkam dan diselamatkan dalam bentuk tulisan, dan ternyata dari segi kuantitas dan kualitas, tradisi lisan itu luar biasa kayanya dan beraneka ragam. Dalam tradisi lisan setiap daerah terungkap kreativitas bahasa yang luar biasa, dari hasil tradisi lisan tersebut manusia dapat mewujudkan

\footnotetext{
${ }^{14}$ Ridwan Tohopi, Budaya Islam Lokal Gorontalo, (Gorontalo: Sultan Amai Press, 2012) h. 157
} 
hakikat mengenai dirinya sendiri sehingga sampai sekarangpun ciptaan itu mempunyai nilai dan makna yang luhur. ${ }^{15}$

Keberadaan budaya Islam Gorontalo yang dimanifestasikan dalam berbagai bentuk tradisi lisan yang hidup dalam masyarakat memperlihatkan bahwa Islam menjadi bagian yang tak terpisahkan dari keseharian hidup masyarakat Gorontalo. Beberapa analisis dari sejarawan Gorontalo menyatakan bahwa tradisi lisan yang bernuansa agama ini sudah dibudayakan sejak zaman dulu dalam rangka memberantas budaya animisme yang masih hidup pada masa awal Islam di Gorontalo. Menurut Buloto, bahwa perayaan Isra Mi'raj secara tradisional (me'eraji) telah dimulai sejak pemerintahan Raja Eyato dan Huhu Popa pada tahun 1673. ${ }^{16}$

Berbagai macam tradisi lisan yang hidup dalam masyarakat hingga hari ini diduga adalah kontribusi dari periode Islam dalam sejarah Gorontalo. Periodisasi sejarah Gorontalo dapat dibagi menjadi lima periode yakni: a) Periode Pra Islam dari tahun 1385 M-1525 M. b) Periode Islam (1550 M-1755 M. c) Periode Kolonial (1889 M-1941 M). d) Periode Kemerdekaan (1945 M-1997 M). e) Periode Reformasi (1997 Msekarang). Budaya Islam dengan tradisi lisannya tidak dapat dipandang hanya sebagai akumulasi dari lima periode zaman tersebut. Masingmasing periode mempunyai fakta empiris yang dikendalikan oleh nilainilai dominan pada zamannya. Sepanjang sejarah kebudayaan Gorontalo, nilai-nilai ideal yang terinternalisasi secara dominan dalam pola progresif demokratis pernah dicapai hanya pada periode Islam. Kebudayaan dengan pola tersebut sudah mengantarkan Gorontalo mencapai puncak kejayaan Islam selama lebih kurang 205 tahun. ${ }^{17}$

Periodisasi sejarah peradaban Gorontalo sebagaimana digambarkan di atas memperlihatkan sumbangsih periode Islam dalam membangun peradaban Islam Gorontalo yang pengaruhnya tetap tersa hingga hari ini. Adat istiadat dan budaya Gorontalo merupakan perpaduan harmonis antara nilai Islam dan nilai-nilai lokal masyarakat Gorontalo. Inilah yang menjadi penanda corak keberagamaan masyarakat Islam Gorontalo.

\footnotetext{
${ }^{15}$ A. Teeuw, Sastra dan Ilmu Sastra, Pengantar Ilmu Sastra (Jakarta: Pustaka Jaya, 1984) h. 10

${ }^{16}$ Ridwan Tohopi, Budaya Islam Lokal Gorontalo, h.77

${ }^{17}$ Ridwan Tohopi, Budaya Islam Lokal Gorontalo, h.79
} 


\section{DiKili Sebagai Satu Varian Budaya Islam Gorontalo \\ 1. Pengertian Dikili beserta aspek-aspeknya dalam budaya Islam lokal Gorontalo}

Kata dikili dalam bahasa Gorontalo memiliki sinonim dengan kata Bahasa Arab zikir, suatu kata yang bersumber dari kata dasar zakara (ذكر) yang berarti menyebut, mengucapkan atau mengingat. ${ }^{18}$ Mungkin kata dikili ini adalah terminologi umum dalam bahasa Gorontalo zaman dahulu untuk melambangkan kegiatan menyebut, mengucap, atau mengingat. Saat ini kata dikili mungkin telah mengalami penyempitan makna hanya merujuk kepada kegiatan dalam tradisi Gorontalo yang berhubungan dengan perayaan maulid Nabi Muhammad saw. Karena pada saat ini kata yang populer dalam bahasa Gorontalo yang sinonim dengan kata zikir adalah kata 'jikiri'. Istilah dikili yang dilaksanakan di Gorontalo lebih difokuskan untuk mengingat kelahiran Nabi Muhammad saw. Secara spesifik kata dikili di Gorontalo diartikan dengan dila kiki ama-amali (lidah kecil yang sedang beramal ${ }^{19}$

Makna substantif yang dikandung kata dikili yang mendorong orang untuk banyak berzikir, mo'eła (mengingat) Allah sebagaimana yang banyak diajarkan oleh Nabi Muhammad saw. Hal ini juga mengandung makna untuk mengingat Nabi Muhammad saw serta ajaran agama Islam yang dibawanya. Semua makna ini memiliki relevansi dengan ajaran Islam yang senantiasa mendorong pemeluknya untuk senantiasa berzikir kepada Allah sebagai sebuah bentuk ketaatan dan ibadah kepada-Nya.

Dikili adalah suatu tradisi yang dilakukan oleh masyarakat Gorontalo mengiringi upacara Maulidan (peringatan hari kelahiran Nabi Muhammad SAW) setiap bulan Rabiul Awal menurut perhitungan tahun Hijriah. Dikili sebagai peninggalan leluhur isinya tertulis tangan dalam satu naskah berbentuk ungkapan dan kisah yang ditampilkan melalui lagu. Naskah yang tersebar dalam masyarakat terdiri atas: bahasa Arab, bahasa Indonesia dan bahasa daerah Gorontalo. Tiga bahasa dalam naskah tersebut ditulis bervariasi. Isi

\footnotetext{
${ }^{18}$ Ahmad Warson Munawwir, Kamus Al-Munawwir Arab Indonesia Terlengkap (Surabaya: Pustaka Progressif, 1997) h. 448

${ }^{19}$ Ellyana Hinta, Simbol Verbal dan Non Verbal dalam Tradisi Maulidan Sebagai Konteks Tradisi Lisan di Gorontalo, h. 150
} 
naskah terdiri atas dua bentuk, yaitu bentuk puisi dan bentuk prosa (cerita). Tradisi ini sudah dilakukan sejak zaman dahulu kala. ${ }^{20}$

Peringatan hari Kelahiran Nabi Muhammad saw selalu menjadi momen yang paling dinanti-nantikan oleh umat Muslim, khususnya di Gorontalo. Pelaksanaannya pun cukup unik dan jauh berbeda dengan perayaan di daerah-daerah lain. Di Gorontalo, peringatan Maulid Nabi Muhammad saw dilaksanakan semalam suntuk, yaitu dimulai setelah shalat Isya hingga pagi hari pukul 09.00 atau pukul 10.00 .

Perayaan Maulid Nabi Muhammad saw secara tradisional yang diisi dengan kegiatan dikili dilaksanakan secara meluas di seluruh wilayah Gorontalo. Kondisi ini menghadirkan suatu suasana khas pelaksanaan dikili yang berlangsung semalam suntuk hingga besok paginya. Bagi sebagian orang utamanya para praktisi dikili, momen ini adalah momen yang penuh berkah dengan banyaknya rezeki yang mereka terima sebagai penghargaan atas profesi mereka sebagai pelaku atau praktisi dikili.

Acara dimulai pembacaan doa tahlilan untuk kemudian dilanjutkan dengan "dikili" (diambil dari kata "dzikir") yaitu alunan zikir, shalawat, dan puji-pujian kepada Allah untuk sang Nabi yang "berulang tahun" hingga pagi menjelang siang. Selama semalam suntuk, para imam, ulama, dan pegawai syara' yang ditunjuk, melantunkan dikili. Dalam acara ini, posisi para pelantun dikili dipisahkan berdasarkan jenis kelamin yang dipisahkan oleh pagar bambu kuning yang dihiasi dengan janur kuning. Pemisahan ini menggambarkan bahwa tradisi ini juga menghormati syariat Islam tentang bagaimana hubungan antara laki-laki dan perempuan dalam Islam. Masing-masing kelompok baik kelompok pria dan wanita membentuk suatu lingkaran yang padat untuk memudahkan setiap orang untuk membantu bila ada orang disebelahnya sudah kelelahan sepanjang malam. Pelantunan narasi dikili dilakukan oleh imam dan ketua-ketua kelompok secara bergantian untuk kemudian diikuti oleh seluruh anggota kelompok secara bersama-sama atau terkadang bergantian atau bersahut-sahutan. Acara ini dilakukan sepanjang malam dengan tentu saja diselingi dengan sedikit istrahat untuk

${ }^{20}$ Salmin Djakaria, Dikili Tradisi Dalam Upacara Maulidan di Gorontalo (Manado: BPSNT, 2007) h. 4 
sekedar menyeruput secangkir teh atau kopi untuk menjaga agar tubuh tetap hangat dan suara tetap terdengar lantang.

Di sinilah wujud pengagungan dan pengorbanan umat muslim di Gorontalo kepada sosok seorang Nabi yang menjadi suri teladan dalam setiap perilakunya. Seolah ingin menunjukkan betapa dalamnya rasa cinta mereka terhadap Nabi Muhammad S.A.W. Masyarakat yang tidak ikut melantunkan dikili pun sebagian berusaha tetap terjaga untuk menyiapkan hidangan untuk para pelantun dikili yang ingin beristirahat sejenak. Sepiring bubur ayam dan secangkir teh atau kopi serta beberapa macam penganan dirasa cukup untuk mengembalikan semangat yang mulai digerogoti rasa kantuk.

Esok harinya, usai prosesi dikili, masyarakat di sekitar mesjid yang merayakan Maulid berkumpul di halaman mesjid untuk berbagi bahkan berebutan kue yang diisi dalam sebuah "tolangga". Tolangga adalah sebuah wadah besar yang dihiasi dengan berbagai macam jenis kue dan makanan seperti nasi putih, nasi kuning, nasi bilindi, telur, dan lain-lain. Tolangga inipun ada yang khusus untuk dibagi-bagikan kepada masyarakat, adapula yang khusus diberikan kepada para imam, ulama, maupun pegawai syara', sebagai "imbalan" atas pengorbanan mereka melantunkan dikili selama semalam suntuk.

Tradisi dikili yang dilaksanakan sebagai bagian dari perayaan maulid Nabi Muhammad saw dalam konteks lokal Gorontalo dipandang sangat bermanfaat bagi masyarakat Gorontalo sekaligus sebagai tanda bahwa masyarakat Gorontalo memiliki adat istiadat yang bernuansa Islami. Beberapa manfaat tradisi dikili antara lain:

1. Mengusir setan

2. Membuat Allah ridho

3. Membahagiakan dan melapangkan hati

4. Menguatkan jasmani dan rohani

5. Menyinari wajah dan hati

6. Membuka pintu rezeki

7. Membuka semua pintu ilmu

8. Menjaga lidah dari perkataan kotor

9. Mendapatkan nikmat

10.Menolak bala. ${ }^{21}$

21 Ellyana Hinta, Simbol Verbal dan Non Verbal dalam Tradisi Maulidan Sebagai Konteks Tradisi Lisan di Gorontalo, h. 151 
Sepuluh manfaat dikili sebagaimana diungkapkan di atas juga dirasakan masyarakat yang menunjukkan manfaat yang mereka rasakan dari pelaksanaan dikili yang selama ini mereka geluti. Bila dihitung secara materil mungkin manfaat yang mereka rasakan terbilang kecil. Akan tetapi manfaat non materil yang sangat besar utamanya yang dirasakan oleh para praktisi dikili. Manfaat non materil inilah yang diyakini sebagai gambaran akan adanya berkah dan ridho Allah swt dikarenakan kecintaan mereka pada sosok Nabi Muhammad saw.

Demikian mengakarnya tradisi dikili dalam masyarakat Gorontalo sehingga menjadi elemen budaya yang tak terpisahkan dengan masyarakat Gorontalo itu sendiri. Bisa jadi tradisi ini telah dirintis pada priode Islam dari peradaban Gorontalo yakni pada tahun $1550 \mathrm{M}$ sampai dengan $1755 \mathrm{M}$. Periode ini yang dipandang oleh para sejarawan Gorontalo sebagai periode yang paling berperan menginternalisasi nilai-nilai ideal Islam dalam kebudayaan Gorontalo. $^{22}$ Meskipun setelah itu cengkeraman kolonialisme menjajah Gorontalo, namun nilai-nilai ideal beserta seluruh bentuk turunannya tetap lestari hingga hari ini. Mungkin hal ini yang menjadi salah satu faktor yang melatarbelakangi Kementerian Pendidikan Nasional mengakui tradisi dikili sebagai warisan budaya tak benda yang berasal dari Gorontalo. ${ }^{23}$

Dengan kenyataan ini terlihat bahwa tradisi dikili memiliki akar sosiolkultural yang dalam dalam komunitas masyarakat Gorontalo. Dengan mayoritas masyarakat Gorontalo yang beragama Islam dan kuat berpegang pada adat, maka berbagai tradisi masyarakat yang di dalamnya terdapat unsure agama dan unsur adat akan mendapat penerimaan yang kuat. Inilah yang menyebabkan mengapa tradisi dikili tetap hidup dan lestari di Gorontalo hingga hari ini.

\footnotetext{
${ }^{22}$ Ridwan Tohopi, Budaya Islam Lokal Gorontalo (Gorontalo: Sultan Amai Press, 2012) h. 79

${ }^{23}$ Lihat Direktorat Internalisasi Nilai dan Kekayaan Budaya Direktorat Jenderal Kebudayaan Kementerian Pendidikan dan Kebudayaan RI, "Dikili" dalam http://warisanbudayaindonesia.info/view/warisan/155/Dikili_(7 Januari 2014)
} 


\section{Karakteristik Kitabi Lo Dikili dan karakteristik pembacanya / pelaku atau praktisi dikili.}

Pelaksanaan ritual maulidan dikili di Gorontalo tidak bisa dipisahkan dari buku bacaan yang disebut Kitabi Lo Dikili. Buku inilah yang menjadi panduan para pelaku dikili dari malam hingga pagi harinya. Teks dikili biasanya berbentuk puisi dan narasi. Teks yang berbentuk narasi terdapat pada semua bagian/judul yang secara keseluruhan berjumlah 18 bagian. Adapun teks yang berbentuk narasi terdiri atas tiga bagian yakni (a) bagian 1-18 memuat 25 narasi yang berbahasa Arab, (b) bagian 1-8 memuat narasi berbahasa Indonesia, dan (c) bagian 9-18, memuat narasi berbahasa Gorontalo. Total narasi berjumlah 50 bagian. $^{24}$

Keseluruhan isi buku ini ditulis dengan aksara Arab Pegon. Biasanya disebut pula Arab Pego atau Arab Jawi, yaitu tulisan dengan huruf Arab atau huruf hijaiyah tapi menggunakan bahasa Jawa. Di daerah lain disebut dengan Arab Melayu karena menggunakan Bahasa Melayu atau Indonesia; atau bahasa lokal lain yang ditulis dengan huruf Arab. Jika dilihat dari kejauhan, tulisan Arab Pegon seperti tulisan Arab pada biasa, namun kalau dicermati sebenarnya susunannya atau rangkaian huruf-hurufnya bukan susunan bahasa Arab. Orang Arab asli tidak akan bisa membaca tulisan ini. ${ }^{25}$

Pemilihan aksara Arab Pegon untuk menulis narasi dalam Kitabi Lo Dikili bisa jadi dikarenakan beberapa alasan yakni 1) Daerah Gorontalo tidak memiliki aksara sendiri, 2) Aksara Arab Pegon itu akomodatif terhadap bunyi vokal dan konsonan yang biasanya muncul dalam bahasa daerah, dimana aksara Arab Hija'iyah tidak bisa mengakomodasinya, dan 3) Penggunaan aksara Arab Pegon akan lebih menonjolkan sisi sakral dari sebuah karya tulis jika dibandingkan hanya ditulis dengan aksara Latin. Mungkin karena tiga alasan inilah maka banyak buku-buku yang menjadi rujukan dari berbagai tradisi lisan Gorontalo yang ditulis dengan aksara Arab Pegon. Meskipun demikian dari informasi yang disampaikan ternyata bahwa dewasa ini tidak semua Kitabi Lo Dikili ditulis dengan aksara Arab Pegon tetapi ditulis dengan huruf Latin karena mungkin banyak

\footnotetext{
${ }^{24}$ Ellyana Hinta, Simbol Verbal dan Non Verbal dalam Tradisi Maulidan Sebagai Konteks Tradisi Lisan di Gorontalo, h. 151

${ }^{25}$ Lihat, Ensiklopedi NU, Arab Pegon, dalam http://www.nu.or.id (9 Januari 2014)
} 
di antara para pembaca kitab ini yang memang tidak bisa membaca aksara Arab Pegon.

Salah satu aspek yang sulit untuk diungkap dari Kitabi Lo Dikili adalah aspek penulisnya. Tidak diketahui dengan pasti siapa yang menulis buku ini. Fenomena seperti ini juga berlaku pada bukubuku yang dibaca dalam tradisi lisan lainnya di Gorontalo. Buku dan isinya adalah warisan turun temurun yang terus menerus dibaca oleh masyarakat Gorontalo setiap momen maulid Nabi tanpa pernah ada yang mempertanyakan siapa penulisnya dan kapan ditulis. Namun belakangan ini ada sebagian sejarawan di Gorontalo yang berasumsi bahwa Kitabi Lo Dikili dan kitab-kitab tradisi lisan lainnya adalah lahir dari era keemasan Islam Gorontalo pada tahun $1550 \mathrm{M}$ sampai dengan $1755 \mathrm{M} .{ }^{26}$ Periode waktu selama 205 tahun ini adalah periode yang melanjutkan periode sebelum Islam. Mungkin karena pada masa ini masih banyak tradisi masyarakat yang masih dipengaruhi oleh budaya-budaya sebelum Islam sehingga para penguasa berupaya mengubah budaya-budaya pra Islam menyisipkan nilai-nilai dan materi-materi Islam dalam budaya masyarakat. Maka lahirlah beragam budaya masyarakat Gorontalo yang bernuansa Islam dan tetap dilestarikan hingga kini.

Dari aspek pelaku atau praktisi dikili terlihat ada karakteristik khas yang tidak berlaku umum. Para pelaku tradisi dikili ini memiliki karakteristik yang khas. Secara umum mereka adalah tokoh-tokoh agama di kampung yang posisinya dikukuhkan secara adat. Dan sebagian lainnya adalah masyarakat biasa yang memang punya kecenderungan mencintai tradisi dikili ini.

Dari aspek pendidikan secara umum terlihat bahwa para praktisi dikilibukanlah orang yang terpelajar secara formal dan tinggi. Mereka secara tradisional belajar dari para imam dengan kurikulum yang biasanya sudah terpola secara paten sumber-sumber belajarnya demikian halnya metode yang digunakan. Dengan pola pendidikan seperti ini, dapat dikatakan bahwa pilihan untuk menjadi praktisi, pelaku, dan pemelihara tradisi dikili bukanlah sebuah pilihan rasional dengan pertimbangan material, tetapi lebih sebagai sebuah pilihan yang dilandasi oleh rasa hormat kepada guru dan selanjutnya kepada Nabi Muhammad saw, sehingga merekalah yang memegang tongkat estafet kelanjutan dari tradisi dikili dalam masyarakat Gorontalo.

${ }^{26}$ Ridwan Tohopi, Budaya Islam Lokal Gorontalo, h. 79 
Tradisi dikili tetap lestari di daerah Gorontalo hingga saat ini karena keberadaan masyarakat yang tetap mencintai budaya ini dan terutama para pelaku tradisi dikili ini. Secara umum para pelaku dikili ini adalah mereka yang posisi sosialnya dalam masyarakat dekat dengan agama. Mereka itu yang dalam bahasa daerah disebut dengan lebi, sarazla'a, iłnamu, hatibi. Dalam keseharian mereka adalah imam dan khatib kampung, para pembaca doa di kuburan, atau para pemimpin selamatan dalam masyarakat Gorontalo. Dari aspek pendidikan agama, mereka ini bahkan berada pada level rendah karena hanya memperoleh pengetahuan agama di level madrasah atau bahkan tidak pernah sama sekali. Mereka hanya bermodalkan kemampuan mengaji, membaca Barzanji, bacaan shalawat, serta gemar kepada ajaran tarekat khususnya dari alirian Qadiriyah yang memang banyak pengikutnya di daerah Gorontalo. Dari karakter ini dapat dikatakan bahwa para pelaku dikili ini tergolong kepada masyarakat Islam tradisional.

Dengan karakter seperti ini, maka tidak mengherankan apabila para pelaku dikili tidak pernah mempertanyakan asal usul penulis buku Kitabi Lo Dikili serta kapan ditulisnya. Bagi mereka, kitab ini adalah warisan sakral yang memang cuma untuk dilaksanakan dan tidak untuk diubah. Karena tradisi dikili adalah peristiwa adat yang memang telah ditetapkan sejak lama dan tidak boleh diganti. Hal ini berkaitan dengan sumpah adat berikut ini: Didu boli-didu boli, Aadati li mongoli, didu boli-boliye, wonu bolo boliyalo, lipu tia maa'alo, Ti Limutu Hulondhalo, janji tia ngopanggalo (jangan lagi-jangan lagi dirubah, adat kamu, tetaplah sebegitu, jika hendak diganti, negeri ini akan bubar, Limboto-Gorontalo, karena janji seikat) ${ }^{27}$. Sumpah adat inilah yang menjadi kekuatan tradisi dikili di Gorontalo dan para pelaku dikili inilah yang menjadi basis penerus tradisi ini hingga tetap lestari dari waktu ke waktu.

\section{Pesan-pesan moral dalam dikili yang relevan dengan dakwah Islamiyah.}

Dari perspektif dakwah Islamiyah, pelaksanaan ritual maulidan dikili di Gorontalo memiliki hubungan yang sangat erat. Sebagai tradisi yang dilatar belakangi semangat untuk memperingati kelahiran Nabi Muhammad saw, maka berbagai aspek kegiatan yang

\footnotetext{
${ }^{27}$ S.R. Nur dkk, Kerakyatan Sebagai Azas Ketatanegaraan Adat Sulawesi, h. 21
} 
dilaksanakan berkaitan dengan peristiwa ini selalu sarat dengan nilainilai spiritual.

Narasi-narasi yang dibacakan dalam tradisi lisan dikili penuh dengan puja-puji kepada pemimpin besar umat Islam Nabi Muhammad saw. Pada aspek inilah relasi dengan dakwah Islamiyah itu tampak. Islam telah menjadikan Nabi Muhammad saw sebagai suri tauladan utama bagi umat Islam dalam segala hal. Hal ini seperti dinyatakan dalam firman Allah swt dalam QS Al-Ahzab (33) : 21

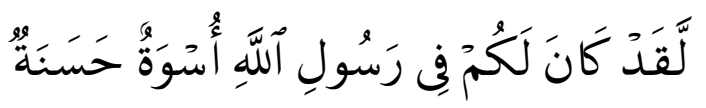

Terjemahnya:

"Sesungguhnya telah ada pada (diri) Rasulullah itu suri teladan yang baik bagimu.." 28

Dari ayat di atas tampak bahwa ada pengakuan Allah swt bahwa pada diri Rasulullah saw ada suri tauladan yang baik yang harus dijadikan panutan. Bahkan menurut Al-Hasani, setiap umat Islam wajib hukumnya untuk berpedoman pada perilaku Nabi Muhammad saw dan bukan kepada yang lainnya. ${ }^{29}$ Pernyataan ini diperkuat oleh pendapat Al-Alusi yang menyatakan bahwa seharusnya bagi setiap muslim untuk menjadikan perkataan dan perbuatan sebagai dasar dari semua perilakunya. Termasuk juga pada jalan yang ditempuh oleh para sahabat, tabi'in, dan para imam mujtahid yang senantiasa dalam kebajikan dan keridhaan Allah swt. ${ }^{30}$

Dua pendapat di atas mewakili pendapat mayoritas para ulama yang tidak ada keraguan dalam pendapat mereka tentang posisi Nabi Muhammad saw sebagai panutan utama bagi umat Islam. Atas dasar inilah, maka berbagai model kajian dan pembelajaran, kegiatankegiatan, dan tradisi-tradisi yang menjadikan Nabi Muhammad saw sebagai tokoh sentralnya dapat ditemukan dalam masyarakat Islam di manapun di dunia ini. Salah satunya dapat ditemukan dalam tradisi

\footnotetext{
${ }^{28}$ Departemen Agama RI, Al-Qur'an dan Terjemahnya (Semarang: PT Karya Toha Putra, 1996) h. 336

${ }^{29}$ Muhammad bin Ismail bin Shalah bin Muhammad Al-Hasani, Raf'u Al-Astar Li Ibta邓 Adillat Al-Qa宅lin Bifana>Al-Nar Juz I (Cet. I, Beirut: Al-Maktab Al-Islami, 1405 H) h. 29

${ }^{30} \mathrm{Abu}$ Al-Ma`ali Mahmud Syukri bin Abdullah bin Muhammad bin Abi Al-Tsana?AlAlusi, Ghayłah Al-Amaæ̀i Fi Al-Radd 'Ala Al-Nabhä̀i Juz II(cet. II, Riyałh: Maktabah Al-Rusyd, 1422 H-2001 M) h. 372
} 
dikili di Gorontalo. Naskah-naskah yang dibacakan dalam tradisi dikili di Gorontalo sarat dengan pesan moral yang rujukan utamanya adalah pribadi Nabi Muhammad saw. Beberapa potongan narasi dalam Kitabi Lo Dikili akan diungkapkan dalam narasi berikut ini:

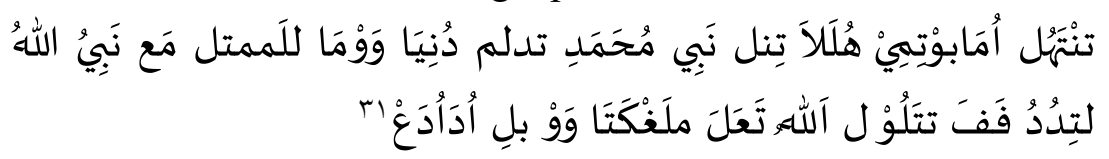

Tontahu louma bo timi hulala tinelo Nabi Muhammadi SAW todelomo dunia. Wawu ma lolamemetolomao nabiyullah lotidudupapa totalu lo Allahu taala molanggata wawu boli uda-udaa Terjemahnya:

"Dengan cahaya bulan yang begitu bersinar tampak pada pribadi Nabi Muhammad saw. Ia pun bersujud di hadapan Allah swt Zat Yang Maha Tinggi lagi Maha Besar. “

Kalimat di atas menunjukkan makna pencerahan terutama dari potongan narasi: hulala tinelo Nabi Muhammadi SAW, yang menggambarkan bahwa kelahiran Nabi Muhammad saw merupakan penerang bagi umatnya. Hal ini disyaratkan dengan cahaya bulan yang begitu benderang ketika beliau lahir ke dunia ini sehingga beliaupun langsung bersujud. Adapun makna sinar bulan itu ialah keluhuran, kesucian, kebaikan, dan keindahan perilaku, sifat, serta kepribadian Nabi Muhammad saw. Sedangkan kalimat lotidudupapa totalu lo Allahu taala molanggata wawu boli uda-udaa, bersujud kepada Allah swt yang Maha Tinggi lagi Maha Besar bermakna menyerahkan diri lahir batin, pengakuan atas kerendahan makhluk, serta pengakuan pengabdian kepada Yang Maha Kuasa.

Dalam narasi di atas digambarkan sosok Nabi Muhammad saw sebagai sosok manusia yang agung, sehingga digambarkan kehadirannya di dunia ini ibarat cahaya terang yang hadir di tengah kegelapan dunia. Nabi Muhammad saw hadir di tengah dunia yang dipenuhi oleh kegelapan kekafiran kepada Allah swt yang ditandai dengan kejahiliyahan penduduk Mekah dan sekitarnya yang sibuk menyembah berhala-berhala dan melakukan berbagai tindakan dosa lainnya.

Dalam situasi ini, Nabi Muhammad saw hadir membawa ajaran Islam yang pokok ajarannya adalah Tauhid, Allah swt Yang

\footnotetext{
${ }^{31}$ Sumber: Kitabi Lo Dikili
} 
Esa, dan hanya Dialah yang patut untuk disembah. Ajaran Tauhid inilah yang disebarkan Nabi Muhammad saw kepada seluruh penduduk Mekah menggantikan penyembahan terhadap berhalaberhala yang diciptakan mereka sendiri. Dan ajaran tauhid ini pula yang tetap menjadi materi dakwah Islamiyah hingga hari ini.

Dari uraian inilah terlihat bahwa potongan narasi yang dibacakan dalam perayaan tradisi dikili memiliki nilai ajaran dakwah yang relevan untuk terus disampaikan kepada umat Islam dari dulu hingga kini bahkan sampai kapanpun.

Narasi selanjutnya dalam Kitabi Lo Dikili adalah:

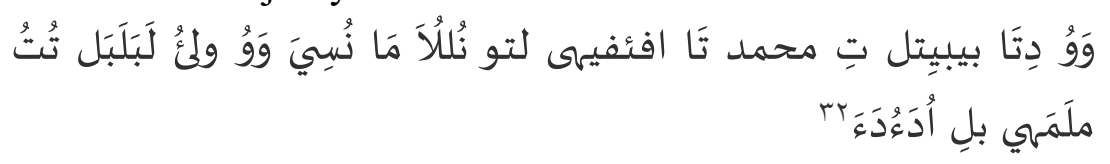

"Wawu deta boyi-boyitolo ti Muhammadi ta ilo piyo-piyohe lotonulola manusia molamahe wawu boli uda-udaa"

Terjemahnya:

"Dan dialah Nabi Muhammad saw, manusia terbaik halus budi pekertinya dan diagung-agungkan kebesarannya."

Narasi di atas menggambar Nabi Muhammad saw sebagai manusia terbaik baik dari aspek fisik maupun aspek non fisiknya berupa akhlak, moralitas, budi pekerti, tingkah lakunya. Semua hal inilah yang membuat Nabi Muhammad saw menjadi manusia terbaik yang dipuja puji sepanjang zaman, tidak saja hanya oleh manusia tetapi oleh Allah swt dan malaikatnya. Personifikasi kepribadian Nabi Muhammad saw dengan jelas diungkapkan dalam Kitab Al-Baranji dengan istilah ahsanu khalqan wa khuluqan ( آحسَنْ خَلًَا وَ خْلْقًا ), yang menggambarkan sosok Nabi Muhammad saw sebagai ciptaan terbaik dilihat dari aspek fisik dan akhlaknya.

Potongan narasi dikili di atas menggambarkan bahwa kelebihan-kelebihan Nabi Muhammad saw sebagai manusia agung . Puja puji yang muncul dalam narasi dikili ini memang merupakan hal yang tidak mengherankan bagi umat Islam yang memang memposisikan pribadi Nabi Muhammad saw dalam posisi yang tinggi. Hal ini tidak terlepas dari pujian Allah swt terhadap beliau di dalam Al-Qur'an yang disebut dengan uswah hasanah.

\footnotetext{
${ }^{32}$ Sumber: Kitabi Lo Dikili
} 
Gambaran tentang keluhuran akhlak Nabi Muhammad saw yang disampaikan melalui potongan-potongan narasi yang dibacakan dalam tradisi dikili, hanyalah salah satu medium penyampaian hal ini di antara ribuan media lainnya yang ada dalam kehidupan kaum muslimin. Keluhuran akhlak Nabi Muhammad saw adalah tema sentral dakwah Islamiyah dari dulu hingga hari ini. Terlebih di zaman modern ini yang ditandai dengan runtuhnya nilai-nilai moralitas dalam kehidupan sosial kemasyarakatan, maka ajaran tentang akhlak Nabi Muhammad saw menemukan momentum yang tepat untuk disebarluaskan sebagai upaya memperbaiki moralitas zaman.

Nilai-nilai akhlak Nabi Muhammad saw yang banyak muncul dalam potongan-potongan narasi yang dibacakan dalam perayaan dikili sungguh memiliki peranan yang signifikan dalam konteks dakwah kultural pada masyarakat Gorontalo.

Narasi selanjutnya yang menggambarkan keagungan Nabi Muhammad saw adalah sebagai berikut:

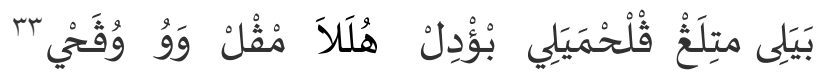

"bayaliyo motilango pilo humaya liyo bo odelo hulala mopulu wau wopahui"

Terjemahnya:

"wajahnya (Muhammad) begitu bercahaya diumpakan sebagai bulan empat belas malam."

Dalam narasi di atas terdapat kontra diksi antara penyataan "wajahnya (Muhammad ) begitu bercahaya", dan pernyataan yang mengumpakan wajahnya dengan "bulan empat belas malam", padahal dalam kenyataannya bulan yang terang benderang cahayanya adalah "bulan lima belas malam". Hal ini dikarenakan bulan "lima belas malam" itu adalah bulan yang cahayanya sempurna, dan kesempurnaan itu hanyalah milik Allah swt Sang Pencipta. Oleh karena Nabi Muhammad saw tidak sesempurna Penciptanya sehingga hanya diumpamakan dengan "bulan empat belas malam", sebagaimana yang diungkapkan di atas. Hal ini merupakan makna fisiknya, dan makna ubudiyahnya ialah simbol cahaya merupakan keluhuran, ketinggian budi, ketinggian imannya, moralnya, serta kemuliaan akhlaknya, kesucian jiwa dan kepribadiannya.

\footnotetext{
${ }^{33}$ Sumber: Kitabi Lo Dikili
} 
Aspek yang menonjol dalam potongan-potongan narasi dalam Kitabi Lo Dikili adalah aspek tauhid dan akhlak. Kedua aspek ini adalah aspek yang penting dari ajaran Islam. Tauhid merupakan landasan berdirinya ajaran Islam, dan akhlak adalah aspek operasional dari ajaran Islam.

Kedua hal ini juga adalah aspek yang tak dapat dipisahkan dari sosok Nabi Muhammad saw dalam perjalanan dakwahnya. Beliau datang ke dalam suatu masyarakat yang kontra tauhid karena menyembah berhala. Dan akhlak beliaulah yang banyak menarik orang untuk masuk ke dalam Islam.

Kedua aspek ini pula yang menjadi tema sentral dakwah Islamiyah yang disampaikan oleh para mubalig dari dulu hingga kini. Dari aspek ini dapat dikatakan bahwa potongan-potongan narasi dalam Kitabi Lo Dikili memiliki muatan nilai-nilai dakwah yang senantiasa relevan dengan dinamika dakwah Islamiyah khususnya dalam masyarakat Gorontalo sebagai pemilik dari tradisi maulidan bernama dikili.

Demikianlah beberapa contoh narasi yang terdapat dalam Kitabi Lo Dikili yang mempunyai relevansi dengan dakwah Islamiyah. Narasi-narasi tersebut menyampaikan pesan-pesan moral tentang keagungan Nabi Muhammad saw secara puitis namun sarat makna dan ajaran yang luhur. Merupakan tugas dari dakwah Islamiyah untuk mengelaborasi pesan-pesan moral dalam naskah dikili untuk menjadikannya sebagai materi pembahasan dakwah yang lebih luas lagi. Satu hal yang pasti bahwa dikili dan Kitabi Lo Dikili tidak hanya sebagai tradisi lisan merayakan bulan maulid di Gorontalo, tetapi juga menjadi kitab penuh dengan pesan moral yang bisa menjadi landasan materil bagi penyampaian dakwah Islamiyah.

Secara operasional dakwah, narasi-narasi dikili yang dilantunkan dalam perayaan maulid Nabi Muhammad saw dalam tradisi Islam di Gorontalo menggunakan pendekatan dakwah kultural dengan metode al-lisart. Pendekatan dakwah kultural adalah suatu pendekatan dakwah yang bersandar pada kultur atau budaya masyarakat obyek dakwah. Pemilihan pendekatan ini lebih didasarkan pada asumsi bahwa penerimaan dakwah akan lebih mudah bila melibatkan unsur-unsur yang dekat dengan kehidupan obyek dakwah, sehingga akan melahirkan kesan bahwa dakwah adalah suatu hal yang dekat dengan kehidupan mereka, bahkan merupakan bagian 
dari kehidupan mereka bukan suatu hal yang asing sehingga lebih mudah diterima masyarakat. Adapun metode al-lisam lebih dikarenakan teks-teks narasi dikili itu diucapkan, dibacakan, atau dilagukan sehingga pesan-pesannya sampai kepada obyek dakwah melalui perantaraan lidah/mulut dan diterima oleh pendengaran. Metode dakwah al-lisat adalah metode dakwah yang bahkan sudah dipraktekkan oleh Nabi Muhammad saw sejak pertama kalinya Islam didakwahkan dan tetap relevan hingga hari ini.

Secara keseluruhan, penelitian ini telah menyajikan dikili menjadi salah satu medium dakwah alternatif di luar model dan pendekatan dakwah konvensional yang berlaku selama ini. Medium dakwah alternatif ini bukan dimaksudkan untuk menggantikan pendekatan yang sudah eksis, akan tetapi memberikan pilihan yang lebih luas dalam berdakwah khususnya dalam menghadapi kelompok masyarakat tertentu dalam seluruh lapisan masyarakat Islam Gorontalo.

\section{Kesimpulan}

Dikili dalam bahasa Gorontalo memiliki makna sinonim dengan kata zikir dalam Bahasa Arab yang berarti mengingat. Kata dikili juga bisa dimaknai sebagai mo’'ła (mengingat) atau mopo'eła (mengingatkan) yakni mengingat Allah swt melalui keagungan Nabi Muhammad saw dan mengingatkan pendengar tentang keagungan Allah swt dan kemuliaan Nabi Muhammad saw. Meskipun demikian kata dikili itu sendiri merupakan akronim yang menunjukkan maknanya sendiri yakni dila kiki ama-amali yang mengandung makna lidah manusia (yang kecil) sedang beramal dengan berzikir.

Kitabi Lo Dikili adalah kitab yang dibaca dalam perayaan dikili. Secara umum kitab ini memuat narasi dengan tiga bahasa yakni Arab, Indonesia, dan Gorontalo yang awalnya ditulis dengan huruf Arab Pegon, dan akhir-akhir ini ada yang ditulis dengan huruf Latin. Adapun para pembacanya adalah para tokoh agama di kampung seperti İnamu, Lebi, Sara \a'a, dan juga ibu-ibu yang memang menggemari perayaan dikili. Para praktisi dikili ini adalah mereka yang secara keagamaan belajar dalam bimbingan para imam kampung. Mereka mempelajari praktek-praktek keagamaan yang berkaitan dengan kebutuhan masyarakat di kampung seperti baca Barzanji, Tahlilan, dan belajar tasawuf Qadiriah. 
Pesan-pesan moral yang termuat dalam narasi Kitabi Lo Dikili yang relevan dengan dakwah pada umumnya menyangkut dua aspek yakni aspek ajaran tauhid dan aspek ajaran moral / akhlak Nabi Muhammad saw. Kedua aspek ini menonjol karena berkaitan dengan setting sosial yang dihadapi oleh Nabi Muhammad saw ketika berdakwah untuk pertama kalinya di Kota Mekah.

\section{DAFTAR PUSTAKA}

Al-Alusi, Abu Al-Ma'ali Mahmud Syukri bin Abdullah bin Muhammad bin Abi Al-Tsana' Ghayah Al-Amani Fi Al-Radd 'Ala Al-Nabhani Juz II(cet. II, Riyadh: Maktabah Al-Rusyd, 1422 H-2001 M)

Al-Hasani, Muhammad bin Ismail bin Shalah bin Muhammad, Raf'u AlAstar Li Ibtal Adillat Al-Qa 'ilin Bifana' Al-Nar Juz I (Cet. I, Beirut: Al-Maktab Al-Islami, $1405 \mathrm{H}$ )

Direktorat Internalisasi Nilai dan Kekayaan Budaya Direktorat Jenderal Kebudayaan Kementerian Pendidikan dan Kebudayaan RI, "Dikili" dalam http://warisanbudayaindonesia.info/view/warisan/155/Dikili $\quad$ (7 Januari 2014)

Djakaria, Salmin, Dikili Tradisi Dalam Upacara Maulidan di Gorontalo (Manado: BPSNT, 2007)

Ensiklopedi NU, Arab Pegon, dalam http://www.nu.or.id (9 Januari 2014) Hinta, Ellyana, Simbol Verbal dan Non Verbal dalam Tradisi Maulidan Sebagai Konteks Tradisi Lisan di Gorontalo (t.tp: Prosiding Seminar Internasional Multikultural dan Globalisasi, 2012)

Ihromi, T.O., Pokok-pokok Antropologi Budaya (Jakarta: Yayasan Obor Indonesia, 2000)

Kitabi Lo Dikili (Data Kepustakaan tidak ada)

Koentjaraningrat, Manusia dan Kebudayaan di Indonesia (Jakarta: Djambatan, 1980)

Liliweri, Alo, Makna Budaya Dalam Komunikasi Antar Budaya (Jakarta: LKiS Pelangi Aksara, 2003)

Mashadi, Realitas Keagamaan dalam Masyarakat Gorontalo antara Tuntunan Syariat dan Tuntutan Budaya, dalam Sofyan AP Kau 
(Editor) Islam dan Tradisi Kearifan Lokal Gorontalo (Gorontalo, Sultan Amai Press: 2013)

Munawwir, Ahmad Warson, Kamus Al-Munawwir Arab Indonesia Terlengkap (Surabaya: Pustaka Progressif, 1997)

Niode, Alim, dan Elnino, Abad Besar Gorontalo (Gorontalo: Presnas Publishing, 2003)

Nur, S.R., dkk, Kerakyatan Sebagai Azas Ketatanegaraan Adat Sulawesi (Ujung Pandang: Percetakan LEPPEN YBW-UMI, t.th.)

Purwanto, Hari, Kebudayaan dan Lingkungan Dalam Perspektif Antropologi (Yogyakarta: Pustaka Pelajar, 2000)

Teeuw, A., Sastra dan Ilmu Sastra, Pengantar Ilmu Sastra (Jakarta: Pustaka Jaya, 1984)

Tohopi, Ridwan, Budaya Islam Lokal Gorontalo (Gorontalo: Sultan Amai Press, 2012)

Van Vollenhoven, Cornelis, Van Vollenhoven on Indonesian Adat Law (Leiden: KITLV, 2013 ) 